\title{
Symptomatic Efficacy of Aloe Vera 2\% Cream in the Treatment of Chronic Anal Fissure
}

\section{Kronik Anal Fissür Tedavisinde Aleo Vera \%2 Kremin Semptomatik Etkinliği}

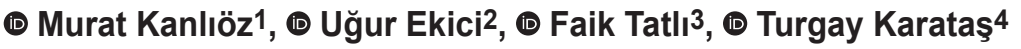 \\ ${ }^{1}$ Çankaya University, Ankara, Turkey \\ 2̇̇stanbul Gelişim University, İstanbul, Turkey \\ ${ }^{3}$ Harran University Faculty of Medicine, Department of General Surgery, Şanlıurfa, Turkey \\ ${ }^{4}$ Inönü University Faculty of Medicine, Department of Anatomy, Malatya, Turkey
}

\section{HIIIII| ABSTRACT}

\begin{abstract}
Aim: Chronic anal fissure (CAF) is a common disease for which various alternative treatment options exist. One of these alternatives is topical treatment with Aloe vera $2 \%$ cream (AVC), reports of which have increased in the literature over the past decade. This study aimed to analyse the efficacy of AVC in the symptomatic treatment of patients with CAF.

Method: Once informed of the treatment method, patients diagnosed with CAF who consented to receive AVC treatment and participate in the study were included in the study. We evaluated four parameters, including duration of stay in the toilet for each defecation, number of defecations per week, haemorrhage during defecation and pain during defecation according to the visual analogue scale, to measure the effectiveness of the treatment in patients with CAF. We posed the same questions to patients before and four weeks after treatment to explore the efficacy of AVC in the treatment of CAF. In all tests, a level of $\mathrm{p}<0.05$ was considered significant.
\end{abstract}

Results: Of the patients, $79.5 \%$ (66) were female and 20.5\% (17) were male. The mean age was $32.6 \pm 9$ years. The median, minimum and maximum number of positively changing parameters were 1,4 and 4 , respectively. Of the 83 patients, $81.9 \%$ (68) said that the treatment was successful and $18.1 \%$ (15) stated that it was not. In all four parameters, the changes were significant $(\mathrm{p}<0.001)$.

Conclusion: We recommend AVC as a complementary or alternative treatment for CAF.

Keywords: Anal fissure, symptomatic treatment, aloe vera cream, defecation pain, haemorrhage

\section{|l||l||l| ÖZ}

Amaç: Kronik Anal fissür (CAF) toplumda yaygın olarak görülen bir hastalıktır. Tedavisi ile ilgili birçok alternatif mevcuttur. Bunlardan biri de son on yılda gittikçe artan oranda yayınlarla karşımıza çıan aleo vera \%2 krem (AVC) ile topikal tedavidir. CAF hastalarında AVC'nin semptomatik tedavideki etkinliğini araştırmak istedik.

Yöntem: Muayenede CAF tespit ettiğimiz hastalara tedavi ile ilgili genel bilgilendirme yapıldıktan sonra, AVC tedavisini ve çalışmaya katılmayı kabul eden 83 hasta çalışmaya dahil edildi. CAF hastalarında tedavi etkinliğini tespit etmek için ölçtüğümüz, her bir defekasyon için tuvalette kalma süresi, haftalık defekasyon sayısı, defekasyon esnasındaki kanama ve visuel analog skalaya göre defekasyon esnasındaki ağrı olmak üzere toplam dört parametreyi değerlendirdik. Hastalara tedavi öncesinde ve tedaviye başlandıktan dört hafta sonrasında aynı sorular sorularak CAF tedavisinde AVC'nin etkinliğini araştırdık. Tüm testlerde anlamlılık düzeyi p<0,05 olarak kabul edilmiștir.

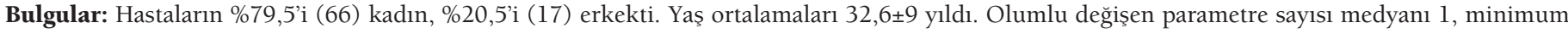
0, maksimum 4 olarak gözlenmiştir. Çalışmaya katılan 83 hastanın \%81,9’u (68) tedavinin faydalı olduğunu, \%18,1’i (15) faydalı olmadığını ifade etmiştir. Ölçtüğümüz dört parametrenin tamamında izlenen değişimler anlamlıydı $(\mathrm{p}<0,001)$.

Sonuç: CAF tedavisinde ciddi semptomatik fayda sağlayan AVC tedavisini tamamlayıcı veya alternatif tedavi seçeneği olarak önermekteyiz. Anahtar Kelimeler: Anal fissür, semptomatik tedavi, aleo vera krem, dışkılama ağrısı, kanama 


\section{Introduction}

Anal fissure (AF) is an ulcer in the anal canal extending from the dentate line to the anal verge, which is classified either as acute or chronic. A fissure that does not regress despite treatment within 8 weeks is called a chronic anal fissure (CAF). Of all AFs, $90 \%$ are located in the posterior midline, while the majority of the rest are in the anterior midline, and a small proportion occur in regions outside the midline. ${ }^{1}$ It would be worthwhile to look at the causes such as Crohn's disease, ulcerative colitis, tuberculosis, syphilis, human immmunodeficiency virus, colon malignancy, etc. of fissures located outside the midline. ${ }^{2}$ CAF leads to an increase in internal anal sphincter pressure and a decrease in the blood flow of the posterior AF line. ${ }^{3}$ As a consequence of such an increase in anal sphincter pressure, defecating would take more time and be painful. A diet of fibrous foods and hot-water bathing in hip baths would be useful. Apart from surgical treatment methods, topical therapies, including lidocaine, steroids, nifedipine, glyceryl trinitrate, Aloe vera and local BOTOX applications are included in the treatment options. ${ }^{4}$ There exist exceptional publications on the topical effects of $2 \%$ Aloe vera powder-containing cream on the treatment of CAF. Aloe vera is a cactus-type plant of African origin belonging to the Liliaceae family and exists in 360 varieties. The stem of the plant's leaves contains a large amount of gelatinous and highly viscous liquid. It constitutes a powerful antioxidant rich in amino acids and vitamins. Owing to its content of strong antioxidant agents, it has antifungal, antibacterial and immunomodulatory effects on wound healing. ${ }^{6}$ Aloe vera has been traditionally used for the treatment of haemorrhoids, anal fissures and burns for many years. Studies conducted on animals have proven that Aloe vera can help accelerate wound healing. ${ }^{7}$ We undertook this study to explore the efficacy of Aloe vera $2 \%$ cream (AVC) in the symptomatic treatment of patients with CAF.

\section{Material and Methods}

This study was conducted in Ankara in 2019. Patients who applied to the general surgery outpatient clinic and were diagnosed with CAF after examination were included in the study. However, the study excluded those who had inflammatory bowel disease, concomitant perianal region disease, diabetes mellitus, atypical fissure, colon malignancy and immunosuppressive disease. After informing patients of the treatments for CAF, a study group was formed, which consisted of 83 patients with CAF who consented to receive AVC treatment and participate in the study. Apart from their demographic information, the patients were asked questions about defecation, and their responses were recorded. The questions posed to the patients before treatment (BT) and four weeks after treatment (AT) to evaluate the treatment results included the following:

1. How long do you stay in the toilet for each defecation?

- Up to five minutes

- 6 to 10 minutes

- 11 to 15 minutes

- More than 15 minutes

2. Does haemorrhage occur during each defecation?

- Yes, it occurs during each defecation

- It often occurs

- It rarely occurs

- No, it never occurs

3. The patients were asked to score their pain from 10 to 10 , " 0 " being indicative of no pain during defecation and " 10 " being indicative of an unbearable pain, according to the visual analogue scale.

4. How many times a week do you defecate?

The efficacy of AVC topical treatment was evaluated by posing the same four questions to the patients with CAF in the periods BT and AT. The AT questions were answered on the basis of the last week of the 4-week treatment. The patients were prescribed AVC and were informed on its usage. Then, the patients were advised to apply AVC to the anal area three times a day and at a volume of one $\mathrm{cm}^{3}$ during each application.

\section{Statistical Analysis}

We used median, minimum (min) and maximum $(\max )$ values to define the discrete numeric data, and performed a Wilcoxon paired-sample test in the comparison thereof. The categorical data were shown in numbers (percentage), and the marginal homogeneity test was used in the comparison. In all tests, a level of 0.05 was considered significant.

\section{Results}

The study included a total of 83 patients, of whom 66 $(79.5 \%)$ were females and $17(20.5 \%)$ were males. The median age was 32 (min. 18 - max. 56), and the mean age was $32.6 \pm 9$ years.

The number of those who had no haemorrhage during defecation was 13 BT, which reached 21 AT. The number of patients with haemorrhage during each defecation decreased from nine BT to two AT (Table 1).

The number of patients who spent 10 minutes or less in the toilet for defecation was $11 \mathrm{BT}$ and reached to 24 in the period AT. The number of patients who spent more than 15 minutes in the toilet for defecation decreased from 35 (BT) to 17 (AT) (Table 2). 
Table 1. Bleeding during each defecation

\begin{tabular}{|c|c|c|c|c|c|c|}
\hline \multicolumn{7}{|c|}{ Bleeding in defecation after treatment } \\
\hline \multirow{4}{*}{$\begin{array}{l}\text { Bleeding in } \\
\text { pre-treatment } \\
\text { defecation }\end{array}$} & Yes & $2(2.4)$ & $4(4.8)$ & $3(3.6)$ & $0(0)$ & $9(10.8)$ \\
\hline & Often yes & $0(0)$ & $17(20.5)$ & $12(14.5)$ & $0(0)$ & $29(34.9)$ \\
\hline & Rarely yes & $0(0)$ & $0(0)$ & $24(28.9)$ & $8(9.6)$ & $32(38.6)$ \\
\hline & Total & $2(2.4)$ & $21(25.3)$ & $39(47.0)$ & $21(25.3)$ & $83(100)$ \\
\hline
\end{tabular}

$\mathrm{p}<0.001$

Table 2. Average duration of toilet time for each defecation

\begin{tabular}{|c|c|c|c|c|c|c|}
\hline & & \multicolumn{5}{|c|}{ Defecation time after treatment } \\
\hline & Time & 0-5 minutes & 6-10 minutes & 11-15 minutes & $\geq 16$ minutes & Total \\
\hline \multirow{5}{*}{$\begin{array}{l}\text { Defecation time } \\
\text { before treatment }\end{array}$} & 0-5 minutes & $2(2.4)$ & $0(0)$ & $0(0)$ & $0(0)$ & $2(2.4)$ \\
\hline & 6-10 minutes & $3(3.6)$ & $6(7.2)$ & $0(0)$ & $0(0)$ & $9(10.8)$ \\
\hline & 11-15 minutes & $1(1.2)$ & $8(9.6)$ & $28(33,7)$ & $0(0)$ & $37(44.6)$ \\
\hline & $\geq 16$ minutes & $0(0)$ & $4(4.8)$ & $14(16.9)$ & $17(20.5)$ & $35(44.2)$ \\
\hline & Total & $6(7.2)$ & $18(21.7)$ & $42(50.6)$ & $17(20.5)$ & $83(100)$ \\
\hline
\end{tabular}

$\mathrm{p}<0.001$

Table 3. Weekly defecation numbers

\begin{tabular}{|llll|}
\hline & $\begin{array}{l}\text { Before } \\
\text { treatment }\end{array}$ & $\begin{array}{l}\text { After } \\
\text { treatment }\end{array}$ & $\mathrm{p}$ \\
\hline $\begin{array}{l}\text { Number of weekly } \\
\text { defecations (n=83) }\end{array}$ & $3(1-7)$ & $4(2-14)$ & $<0.001$ \\
$\begin{array}{l}\text { Average number of } \\
\text { defecations per week } \\
(\mathrm{n}=83)\end{array}$ & $3.43 \pm 1.54$ & $4.33 \pm 2.10$ & $<0.001$ \\
\hline
\end{tabular}

Also, the number of patients who defecated four or more times a week increased from 35 in the period BT to 50 in the period AT. The number of median defecations BT increased from 3 (1-7) to 4 (2-14) per week AT ( $<<0.001)$. The median pain score during defecation decreased from 5 (1-9) to 3 (06) AT $(\mathrm{p}<0.001)$ (Table 3$)$.

Of the 83 patients, 19 (22.9\%) stated that there had been no regression in pain during defecation, while 64 (77.1\%) patients reported decreased pain in the post-treatment period. Although there were no patients who reported no pain during defecation BT, 9 patients reported no pain after defecation AT. While the number of patients who reported a pain score of 6 or more before treatment, this number fell to two AT (Tables 4 and 5).

The median number of positively changing parameters AT was 1 (0-4). Of all the patients, 15 (18.1\%) reported no positive changes regarding the parameters in the four questions posed to patients AT, whereas 68 (81.9\%) patients
Table 4. Pain rating between 0 and 10 after defecation according to the visual analogue scale

\begin{tabular}{|c|c|c|}
\hline & $\begin{array}{l}\text { Before } \\
\text { treatment } \\
\text { number of } \\
\text { patients (n) } \\
\text { and \% }\end{array}$ & $\begin{array}{l}\text { After } \\
\text { treatment } \\
\text { number of } \\
\text { patients (n) } \\
\text { and \% }\end{array}$ \\
\hline No pain & $0(0 \%)$ & $9(10.8 \%)$ \\
\hline 1 intensity pain & $1(1.2 \%)$ & $6(7.2 \%)$ \\
\hline 2 intensity pain & $7(8.4 \%)$ & 19 (22.9\%) \\
\hline 3 intensity pain & $13(15.7 \%)$ & $18(21.7 \%)$ \\
\hline 4 intensity pain & $18(21.7 \%)$ & $16(19.3 \%)$ \\
\hline 5 intensity pain & $18(21.7 \%)$ & $13(15.7 \%)$ \\
\hline 6 intensity pain & $13(15.7 \%)$ & $2(2.4 \%)$ \\
\hline 7 intensity pain & $5(6 \%)$ & $0(0 \%)$ \\
\hline 8 intensity pain & $5(6 \%)$ & $0(0 \%)$ \\
\hline 9 intensity pain & $3(3.6 \%)$ & $0(0 \%)$ \\
\hline $\begin{array}{l}10 \text { intensity pain (unbearable } \\
\text { pain) }\end{array}$ & $0(0 \%)$ & $0(0 \%)$ \\
\hline Total & $83(100 \%)$ & $83(100 \%)$ \\
\hline $\begin{array}{l}\text { Pain score during defecation } \\
(n=83)\end{array}$ & $\begin{array}{l}\text { Before } \\
\text { treatment } \\
5(1-9)\end{array}$ & $\begin{array}{l}\text { After treatment } \\
3(0-6)\end{array}$ \\
\hline
\end{tabular}

$\mathrm{p}<0.001$ 
Table 5. Therapeutic usefulness of parameters

\begin{tabular}{lll}
$\begin{array}{l}\text { How many parameters have } \\
\text { improved }\end{array}$ & $\begin{array}{l}\text { Number of } \\
\text { patients (n) }\end{array}$ & Rate (\%) \\
\hline No improvement in parameters & 15 & 18.1 \\
Improvement in 1 parameter & 29 & 34.9 \\
Improvement in 2 parameter & 14 & 16.9 \\
Improvement in 3 parameter & 10 & 12 \\
Improvement in 4 parameter & 15 & 18.1 \\
Total & 83 & 100
\end{tabular}

stated that they had benefited from the treatment in at least one parameter. Of the 68 patients who stated that they benefited from the treatment, an improvement was reported by $29(34.9 \%)$ in at least one parameter, by $14(16.9 \%)$ in at least 2 parameters, by $10(12 \%)$ in at least 3 parameters and by $15(18.1 \%)$ in all parameters (Table 5$)$.

\section{Discussion}

We analysed the answers given by patients with CAF to the four questions posed to evaluate the $\mathrm{BT}$ and $\mathrm{AT}$ results of AVC treatment, including the severity of pain during defecation, the time spent in the toilet for defecation, whether haemorrhage occurred during defecation and the number of defecations per week. Of the 83 patients who received AVC treatment for CAF, 68 (81.9\%) stated that the treatment was useful to a certain extent, and 15 (18.1\%) reported that it did not work. While patients reported a significant decrease in pain scores $\mathrm{AT}$ as a result of the 4-week AVC treatment, no patients reported increased pain or side effects. In their study, Gaj et al. ${ }^{8}$ report that they administered rectal cream containing Aloe vera to AF and grade 3-4 haemorrhoids, which helped to prevent infective complications and reduced anal area discomfort associated with burning and itching in $84 \%$ of their patients. They also noted that the cream containing Aloe vera which was used during the treatment neither showed irritant and allergic effects nor caused skin damage and pharmacological toxicity. ${ }^{8}$

Whereas there were no patients who reported no pain during defecation BT, 9 patients stated that the pain during defecation disappeared AT. Of the 83 patients, 64 (77.1\%) reported that the pain during defecation regressed partially or disappeared completely. However, 18 patients reported no change in pain during defecation AT. Eshghi et al. ${ }^{9}$ report that they used Aloe vera gel on the anal area for four weeks after haemorrhoidectomy, and as a result thereof, the treatment showed significant success in pain relief and wound healing after defecation compared with the control group. In another study, Rahmani et al. ${ }^{5}$ reported statistically significant differences in pain relief, haemorrhage and wound healing after defecation in patients who received AVC treatment for CAF in a comparison of the treatment group with the control group.

With the use of AVC, the median number of defecations per week increased from 3 (1-7) to 4 (2-14) AT. The number of those whose stayed in the toilet for each defecation for 10 minutes or less was $11 \mathrm{BT}$, reaching 24 in the period AT. The duration of defecation and the number of defecations per week are correlated to bowel movements, whereas the healing of the wound in the anal area is associated with the reduction of pain during defecation. We consider the improvement achieved by AVC in those parameters AT as a secondary outcome of wound healing. In their experimental study performed on rats, Brandão et al. ${ }^{10}$ pointed out that the histological analysis performed proved the efficacy of Aloe vera in wound healing. Yet, in another study aiming to analyse the efficacy of Aloe vera in wound healing and conducted on Wistar rats to explore transforming growth factor $-\beta$ gene expression in the wound bed in wound healing using Aloe vera gel, Takzaree et al. ${ }^{11}$ concluded that Aloe vera is effective in wound healing.

One of the important criteria proving wound healing is the presence or absence of haemorrhage during defecation. In our study, the number of those who had no haemorrhage during defecation was $13 \mathrm{BT}$, which reached $21 \mathrm{AT}$. In their study on rats, Davis et al. ${ }^{12}$ created skin damage on rats and administered topical Aloe vera cream in one group and oral Aloe vera in the other. They reported that wound healing was significantly better in both groups as compared with the control group. ${ }^{12}$ In their study on lymphocyte activation in wound healing, Prakoso et al. ${ }^{13}$ pointed out that cream containing $1 \%$ and $2 \%$ Aloe vera had wound-healing potential owing to its ability to increase the proportion of CD4 +/CD8 + lymphocytes in the wound area in their animal experiment on topical application of aloe vera.

Besides our study, many others have demonstrated the effectiveness of topical application of Aloe vera in wound healing. However, Dat et al. ${ }^{14}$ concluded that Aloe vera had no significant efficacy in chronic wound healing in their meta-analysis of 347 cases. They reported that no highquality clinical trial evidence exists to support the use of Aloe vera topical agents for therapeutic purposes in acute and chronic wounds. With this study, we aspire to address some of these unanswered questions.

The scarcity in the number of published studies conducted on the same subject is a limitation of our research. However, the majority of studies in the literature did not clearly 
indicate whether fissures were acute or chronic. In addition, the possible effects of such diseases as inflammatory bowel diseases, diabetes and cancer, which may affect wound healing, as well as additional perianal diseases, could not be ruled out. Our study achieved a more homogenous CAF group by excluding these factors. This may be considered as an advantage in favour of our study.

\section{Conclusion}

Given that AVC leads to significant regression in patients' symptoms, has a weak potential to cause side effects, provides ease of application and incurs low costs in the treatment of CAF, we consider the results obtained to be promising. We recommend AVC as a treatment supportive of or alternative to the existing treatment methods for CAF.

\section{Ethics}

Ethics Committee Approval: This work has been approved by the Institutional Review Board. In our study, "the Principles of the Declaration of Helsinki" were complied with.

Informed Consent: Informed written consent was obtained from patients.

Peer-review: Internally and externally peer reviewed.

\section{Authorship Contributions}

Surgical and Medical Practices: M.K., U.E., F.T., Concept: M.K., T.K., Design: M.K., U.E., F.T., T.K., Data Collection or Processing: M.K., U.E., F.T., T.K., Analysis or Interpretation: M.K., U.E., F.T., T.K., Literature Search: M.K., U.E., F.T., T.K., Writing: M.K.

Conflict of Interest: No conflict of interest was declared by the authors.

Financial Disclosure: The authors declared that this study received no financial support.

\section{References}

1. Herzig DO, Lu KC. Anal fissure. Surg Clin North Am 2010;90:33-44.

2. Jonas M, Scholefield JH. Anal fissür. Gastroenterol Clin North Am 2001;30:167-181.

3. Schouten WR, Briel JW, Auwerda JJ. Relationship between anal pressure and anodermal blood flow. The vascular pathogenesis of anal fissures. Dis Colon Rectum 1994:37:664-66.

4. Terzi C. Anorectal benign diseases. In: Basic Surgery. Ed: Sayek I. Güneş Bookstore. Ankara. 2013;1476-1497.

5. Rahmani N, Khademloo M, Vosoughi K, Assadpour S.Effects of Aloe vera cream on chronic anal fissure pain, wound healing and hemorrhaging upon defection: a prospective double blind clinical trial. Eur Rev Med Pharmacol Sci 2014;18:1078-1084.

6. Habeeb F, Shakir E, Bradbury F, Cameron P, Taravati MR, Drummond AJ, et al. Screening methods used to determine the antimicrobial properties of Aloe vera inner gel. Methods 2007;42:315-320.

7. Keyhanian S. Phenolic constituents in dried flowers of aloe vera (Aloe barbadensis) and their in vitro antioxidative capacity. E. Planta Med 2007;73:599-602.

8. Gaj F, Crispino P. Proctological surgery: advantages derived from the use of an innovative detergent in the post-operative period. Clin Ter 2009;160:211-213.

9. Eshghi F, Hosseinimehr SJ, Rahmani N, Khademloo M, Norozi MS, Hojati O. Effects of Aloe vera cream on posthemorrhoidectomy pain and wound healing: results of a randomized, blind, placebo-control study. J Altern Complement Med 2010;16:647-650.

10. Brandão ML, Reis PR, Araújo LA, Araújo AC, Santos MH, Miguel MP. Evaluation of wound healing treated with latex derived from rubber trees and Aloe Vera extract in rats. Acta Cir Bras 2016;31:570-577.

11. Takzaree N, Hadjiakhondi A, Hassanzadeh G, Rouini MR, Manayi A, Zolbin MM.Transforming growth factor- $\beta$ (TGF- $\beta$ ) activation in cutaneous wounds after topical application of aloe vera gel. Can J Physiol Pharmacol 2016;94:1285-1290.

12. Davis RH, Leitner MG, Russo JM, Byrne ME. Wound healing. Oral and topical activity of Aloe vera. J Am Podiatr Med Assoc 1989;79:559-562.

13. Prakoso YA, Kurniasih. The Effects of Aloe vera Cream on the Expression of CD4+ and CD8+ Lymphocytes in Skin Wound Healing. J Trop Med 2018;2018:6218303.

14. Dat AD, Poon F, Pham KB, Doust J. Aloe vera for treating acute and chronic wounds. Cochrane Database Syst Rev 2012;2:CD008762. 